UDC 332.33

\title{
INTRODUCTION OF LAND MARKET: CURRENT ISSUES AND DEVELOPMENT PROSPECTS
}

Novakovska I. Doctor of Economics, Corresponding Member NAAS

Email:novmailll@ukr.net

National University of Life and Environmental Sciences of Ukraine

Skrypnyk L. PhD in Economics

E-mail: liliia-nahorna@ukr.net

National University of Life and Environmental Sciences of Ukraine

Ishchenko N. PhD in Economics

Email:natalkai@ukr.net

National Aviation University

The peculiarities of the free market of agricultural lands are described. The consequences of the opening of the land market in terms of economic, land and legal components in the system of land relations are presented. The list of conditions for the purchase and sale of agricultural land is highlighted. The specifics of the functioning of the free market of agricultural lands are substantiated. The characteristic of basic normative-legal acts in the sphere of functioning of the land market is given. A comparative analysis of the current state of purchase and sale of land by farms and agricultural holdings. A comparison of the indicators of the number of concluded agreements of purchase and sale of agricultural land, the average value of rent per 1 ha of land, respectively, by region and price fluctuations per 1 ha of land when concluding purchase and sale agreements. The foreign experience of functioning of the market of agricultural lands with the detailing of the factors influencing the further development is analyzed. In particular, the problems and needs in the functioning of the land market of Poland, Brazil, the United States and the United Kingdom are considered. The possibility of introducing an electronic system such as EMBRAESP, which monitors the main indicators of the efficiency of 
the urban real estate market, together with city legislation, land regulations and large public works projects that may affect the behavior of real estate markets.

Key words: land relations, land market, land lease, land legislation.

Formulation of the problem. Experts in the field of land relations identify a number of problems due to which the market of agricultural land had to be opened. Therefore, these problems relate to non-compliance with the legal regime of land use, as well as violation of current land legislation, namely: obtaining legal rights to land, the purchase and sale of which is carried out in violation of certain legal norms; use of various illegal schemes in violation of statutory norms and rules of the moratorium; application of dubious legal schemes aimed at circumventing the lessee's preemptive right to acquire land plots and to indirectly acquire land by legal entities (until 2024) and non-residents of Ukraine.

Consequences of land market opening in terms of economic, land and legal components in the system of land relations:

Economic component: redistribution of the agricultural land market into the ownership of legal entities for their most efficient use (proposals to change and increase the price policy for land).

Legal component: ensuring the legal acquisition of agricultural land.

Land component: intensification of agricultural land use; protection and preservation of land resources from degradation processes; improving the condition of low-yielding lands.

Land ownership or land relations in general have been, remain and will be relevant. After all, land and legal relations such as: purchase and sale, lease, gift, mine, etc., are present in our lives constantly. However, it should be remembered that land is a limited resource, so, of course, all the above agreements should be carried out only with the implementation of measures for the protection and rational use of land.

Analysis of recent research and publications. Prospects and problems of introduction of the market of agricultural lands are devoted to scientific works of DS Dobryaka, J.M. Dorosha, OS Dorosh, A.G. Martina, IG Kirilenko, Yu. O. Lupenko, 
L.Ya. Novakovsky, IO Novakovska, OI Shkuratova and others. However, today there is no consensus on the model of the agricultural land market in Ukraine.

The aim of the study. Analysis of the problems of formation of the free market of agricultural lands at the present stage, determination of the specifics of development, in particular, research and implementation of foreign experience in its functioning.

Results of research and discussion. Undoubtedly, among the main normative legal acts that regulate land relations in Ukraine are, first of all, the Constitution of Ukraine, the Land Code of Ukraine, the Civil Code of Ukraine, the Tax Code of Ukraine, etc. In addition, there are a number of other legislative acts (Table 1).

Characteristics of basic regulations in the field of land market [10]

\begin{tabular}{|c|c|}
\hline The name of the legal act & Functions and tasks \\
\hline $\begin{array}{l}\text { Law of Ukraine "On } \\
\text { Amendments to Certain } \\
\text { Legislative Acts of } \\
\text { Ukraine Concerning the } \\
\text { Conditions of Circulation } \\
\text { of Agricultural Lands" }\end{array}$ & $\begin{array}{l}\text { One of the fundamental documents that became the legal basis } \\
\text { for the so-called launch of the land market. The provisions of } \\
\text { this law regulate and ensure the legal participation of } \\
\text { individuals, legal entities, local governments in various land } \\
\text { legal agreements, including purchase and sale, alienation of } \\
\text { those land plots that have long been subject to a moratorium - } \\
\text { agricultural land. }\end{array}$ \\
\hline $\begin{array}{l}\text { Law of Ukraine "On } \\
\text { Amendments to Certain } \\
\text { Legislative Acts of Ukraine } \\
\text { Concerning the Resolution } \\
\text { of the Issue of Collective } \\
\text { Land Ownership, } \\
\text { Improvement of Land Use } \\
\text { Rules in Agricultural Land } \\
\text { Massifs, Prevention of } \\
\text { Raids and Stimulation of } \\
\text { Irrigation in Ukraine" }\end{array}$ & $\begin{array}{l}\text { Regulates the basic principles of use and disposal of land } \\
\text { plots, which are located within agricultural lands and } \\
\text { protective forest belts. By law, forest belts and field roads are } \\
\text { leased to individuals and legal entities with mandatory } \\
\text { inclusion in the land lease agreement. In particular, the } \\
\text { maximum term of use of land of state, communal and private } \\
\text { property for agricultural needs (emphyteusis), as well as the } \\
\text { term of use of land of state or communal property for } \\
\text { construction (superficies), which may not exceed } 50 \text { years. }\end{array}$ \\
\hline $\begin{array}{l}\text { Law of Ukraine "On the } \\
\text { procedure for allocating } \\
\text { land in kind (on the }\end{array}$ & $\begin{array}{l}\text { Peculiarities of use and disposal of lands remaining in the } \\
\text { collective ownership of a collective agricultural enterprise, as } \\
\text { well as delimitation of unallocated and unclaimed land plots }\end{array}$ \\
\hline
\end{tabular}




\begin{tabular}{|l|l|}
\hline $\begin{array}{l}\text { ground) to owners of land } \\
\text { shares (units)" }\end{array}$ & $\begin{array}{l}\text { and land shares (shares), but which were not allocated in kind } \\
\text { (on the ground) are determined. }\end{array}$ \\
\hline
\end{tabular}

List of conditions for the purchase and sale of agricultural land: only natural persons from Ukraine may be owners of land plots (not more than 100 hectares per 1 citizen); legal entities from Ukraine will be able to buy land from 2024; citizens who have concluded agreements since 2010 have a priority right; until 2030 inclusive, the price per 1 ha of land cannot be lower than the normative monetary value; a notarized identity certificate must be provided, as well as information on exceeding the land ownership limit; payment under all civil law agreements for agricultural land is noncash; the origin of funds for the purchase of land must be documented.

It is prohibited to sell agricultural land plots in the following cases: land plots of state and communal forms of ownership, as well as plots located closer than $50 \mathrm{~km}$ to the state border of Ukraine; foreign citizens before the referendum; legal entities, participants (shareholders, members) or ultimate beneficial owners of which are citizens of the state recognized by Ukraine as the aggressor state or the occupying state; persons belonging to or belonging to terrorist organizations, as well as offshore companies.

According to the provisions of Article 13 of the Law "On the procedure for allocating land in kind (on the ground) to owners of land shares (units)", if before January 1, 2025 the owner of the share / his heir does not register ownership of the land, the land the plot will be recognized as unclaimed and becomes the communal property of the territorial community [10].

Another feature of the free market of agricultural land in Ukraine is that along with the sale of agricultural land, the ban or moratorium on changing the purpose of land has disappeared. If land plots are repurposed for development, the value of agricultural land near large cities or towns will increase, provided that the local urban planning documentation (long-term plan of the settlement or master plan) provides for development in this area. The number of purchase and sale agreements varies by region (Fig. 1). 
Data from a joint project of AgroPolit.com and Zemelka.ua with the support of the new land agency testify to this process. According to expert research for 16 days from 01.07.2021 164 agreements were concluded. Most operations were carried out in Poltava region - 22, Kyiv region - 20, Sumy region - 19 and Luhansk region - 21. Since the beginning of the land market operation, most transactions have been concluded in Kyiv region (Fig. 2).

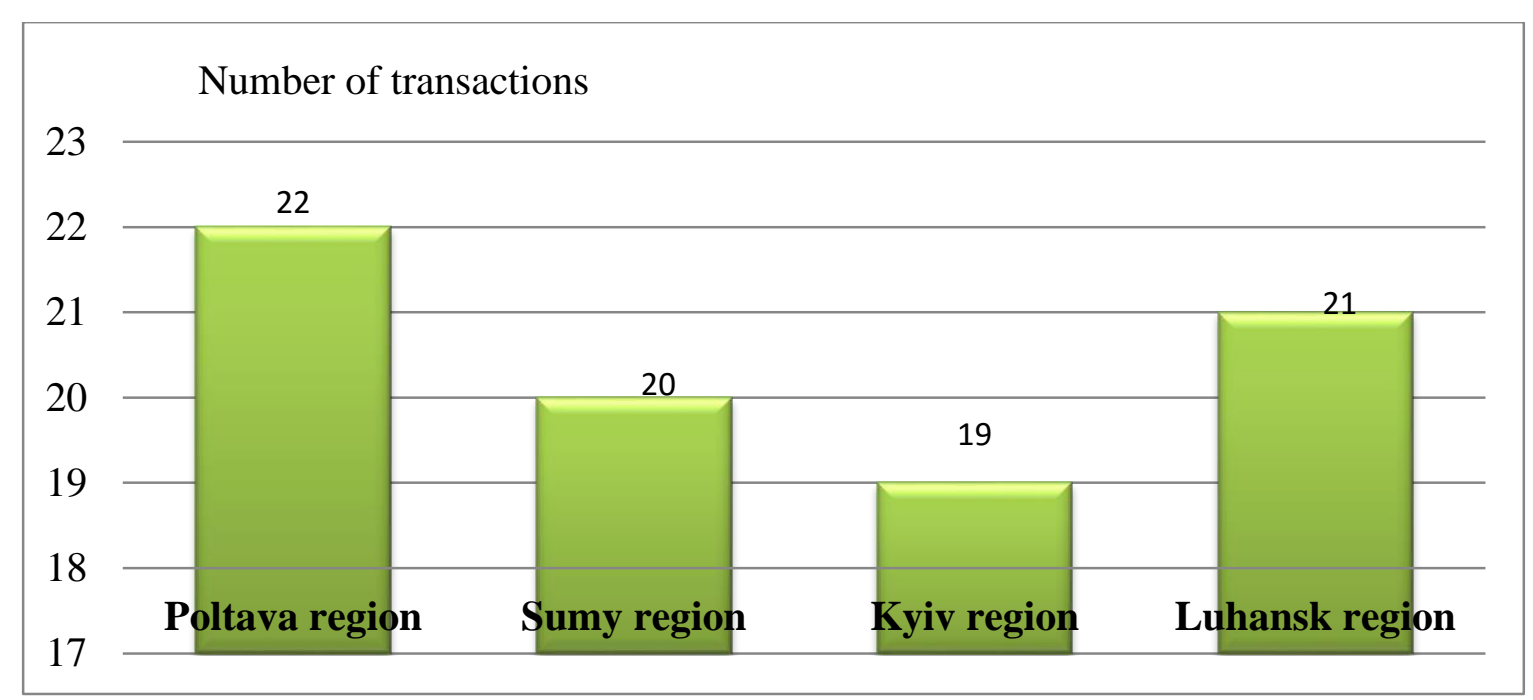

Fig. 1. Distribution of the number of agreements of purchase and sale of agricultural land for the first day from 01.07.2021 by individual regions [11]

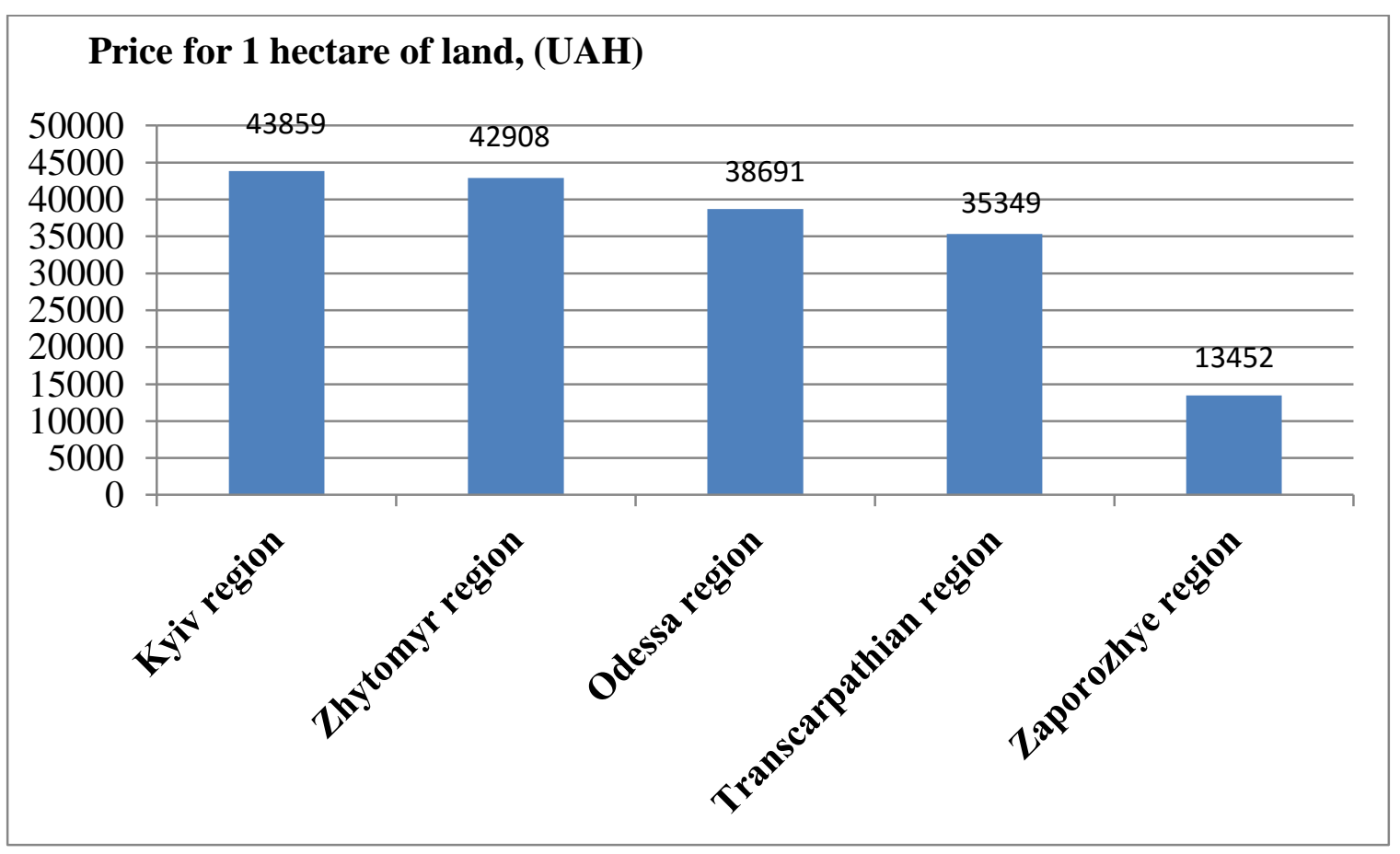

Fig. 2. Fluctuations and distribution of prices per 1 ha of agricultural land in some oblasts (price in UAH) 
According to expert data, the cost of 1 hectare of agricultural land since the beginning of the land market fluctuates within 40 thousand UAH per 1 hectare. According to the research of the project "Land Market in Ukraine. Map of land agreements and land prices from July 1, 2021 ", the average price per 1 hectare of land is UAH 27,628 per hectare. The highest price was recorded in Kyiv region. - UAH 43,859 / ha, then Zhytomyr Region. - 42908 UAH / ha, Odessa region. - UAH 38,691 / ha and Zakarpattia region. - $35349 \mathrm{UAH} /$ ha. The lowest average price is traced in the Zaporozhye region. - $13452 \mathrm{UAH} /$ ha.

It should be noted that the greatest benefit in the case of the sale of agricultural land will be farmers. After all, due to the growth of financial assistance from the state, reducing the loan rate for the purchase of land, as well as the possibility of obtaining land on preferential terms at a price of $\$ 2$ thousand per 1 hectare. the level of profitability of small and medium-sized farms will increase.

It should be noted that according to conclusions of the joint project AgroPolit.com agroholdings, agricultural holdings with an area of 5 to 50 thousand hectares are profitable to buy land if the payback period is 5 years. If such a period exceeds the specified period, the lease is more profitable, because in this case the rate of return on capital is better.

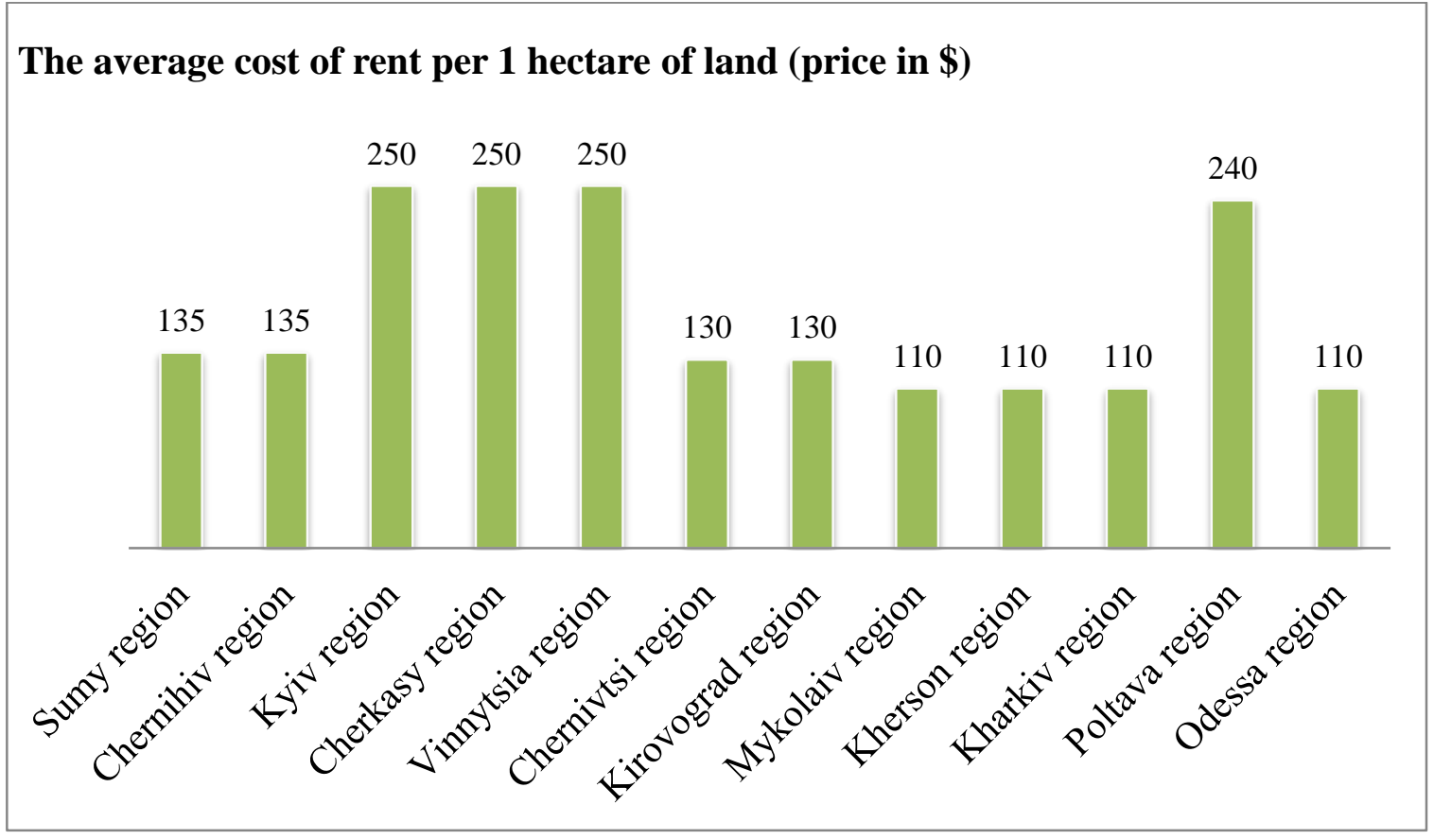


Fig. 3. Fluctuations in the average cost of rent per 1 ha of land (chernozem) (price in \$) in some regions of Ukraine [11]

According to research by experts, the average cost of rent for 1 hectare of land, in particular for chernozems, in Ukraine currently varies: from \$ 30 to 300. In Sumy, Chernihiv regions: sandy soils - from $\$ 30$ to 100 per 1 hectare, for chernozems give $\$$ 120-150 per 1 ha per year. In central Ukraine (Kyiv, Cherkasy, Vinnytsia) - \$160-200, Chernivtsi and Kirovohrad regions - \$120-140, Khmelnytsky - \$ 140-160, Zaporizhia, Kherson, Mykolaiv, Dnipropetrovsk and Kharkiv - \$100-120, Poltava - \$150-200, Odessa - \$ 100-120 (Fig. 3)

Analyzing the functioning of the land market, it is important to analyze the reasons why from 01.07.2021 a really small number of agreements of purchase and sale of agricultural land were concluded. The main ones are the following:

1. In fact, before the launch of the land market, the procedure for checking the buyer of land, the updated procedure for land registration and the mechanism for connecting notaries to the "land base" were presented, so deadlines for quiet preparation burned down. It was impossible to fulfill them under such conditions.

2. At the time of the opening of the free land market, only a small number of notaries had access to the database of the State Land Cadastre. The share of those who actually carry out registration actions with land (certify agreements on the alienation of these lands) is insignificant - according to the interviewed notaries about $5 \%$ of the total. At the same time, having made a mistake, notaries risk losing their license.

3. At present, it is difficult to say how many plots and what area has already been sold in Ukraine. After all, all transactions are an application of intent to sell the land, the actual sale and gift [11].

Due to the above, the foreign experience of the peculiarities of the functioning of the land market needs attention.

Well-known Polish expert Alain Berto notes that the policies embodied in the master plans and zoning regulations are highly inconsistent with the nominal objectives of the rules and will lead to inefficient and expensive spatial models in the city. His work illustrates the value of land price data, regulations, and the spatial organization 
of urban settlements to assess the implications of policies regarding land use, infrastructure, and property taxation [12].

Paul Cheshire of Oberlin College and Stephen Sheppard of the London School of Economics analyze the costs of imperfect land policy or, conversely, the benefits of implementing the right policy, have given rise to a number of systematic efforts to collect and analyze high-quality data on land and real estate markets. different institutional conditions [12].

State regulation of the German agricultural land market takes place through the specialized state institution Agency for Land Management and Sales (Bodenverwertungs-undverwaltungs GmbH - BVVG). The main purpose of the agency is to manage the market turnover of state-owned agricultural land. Its key tasks are: ensuring the privatization of state-owned agricultural land; restitution and distribution of land rights. The BVVG is overseen by the Federal Ministry of Finance and the Ministry of Agriculture.

For example, Brazil has introduced an electronic system called EMBRAESP, which tracks key performance indicators of the urban real estate market, along with city legislation, land regulations and major public works projects that can affect the behavior of real estate markets. Dissemination of information is self-sustaining through contracts with large chains of newspapers, the sale of periodicals, disks containing standard data, and special reports that meet individual requirements. [12].

David Dowall of the University of California, Berkeley (USA) developed the Land Market Assessment System to analyze land and housing markets, which has been used in more than 30 countries, including developed and transition economies. For a relatively modest cost, data are collected through aerial and satellite images, surveys of land intermediaries and secondary sources on population, infrastructure and regulatory framework [12].

Conclusions. The specifics and features of the land market are determined by a wide variety of factors. A significant number of factors affect the market situation, in particular land prices, priority land use goals. However, to fully understand how prices are set, it is important to understand how factors interact. In particular, the spatial 
organization between human lands and agricultural lands should be identified and analyzed to help identify specific risks and related land use changes.

The complexity of the land market and its branching is the result of the forced privatization of common rights in the past. The way land distribution and attitudes toward land occur affects society today. That is why it is important to apply the experience of European countries.

It is necessary to pay attention to the experience of Germany through the creation of a specialized state institution that manages the market turnover of agricultural land, but not only state ownership.

A very important issue is the introduction of an electronic system that would systematize information and monitor the main indicators of the efficiency of the agricultural land market on the example of the EMBRAESP system implemented in Brazil.

\section{References}

1. Zakon Ukrayiny № 1423-IX redaktsiia vid 28.04.2021 r. "Pro vnesennya zmin do deyakykh zakonodavchykh aktiv Ukrayiny shchodo vdoskonalennya systemy upravlinnya ta derehulyatsiyi u sferi zemel'nykh vidnosyn". Available at: https://zakon.rada.gov.ua/laws/show/1423-20\#Text

2. Zakon Ukrayiny № 161-XIV redaktsiia vid 06.10.1998 r. "Pro orendu zemli”. Available at: https://zakon.rada.gov.ua/laws/show/161-14\#Text.

3. Zakon Ukrayiny № 3425-XII redaktsiia vid 02.09.1993 r. " Pro notariat ". Available at: https://zakon.rada.gov.ua/laws/show/3425-12\#Text

4. Dobryak D. S., Shkuratov O. I. (2018) Formuvannya y rozvytok rynkovoho zemel'nykh otnoshenyy na terenakh Ukrayiny. Zbalansovanyy pryrodokorystuvannya. 1, 6-17.

5. Dorosh Y.M, Dorosh O. S. (2015) Metodolohichni pidkhody formuvannya rynku orendy zemel' sil's'kohospodars'koho pryznachennya. Zemlevporyadnyy visnyk. 7, 23-27.

6. Kyrylenko I.H., Kravchuk V.P. (2012) Aktual'ni problemy zemel'noho rynku v Ukrayini. Ekonomika APK. 5, 25-29. 
7. Lupenko YU. O. (2012) Formuvannya perspektyvnoyi modeli sil's'koho hospodarstva Ukrayiny. Ekonomika APK. 11, 10-14.

8. Novakovs'kyy L.YA., Martyn A.H. (2019) Zaprovadzhennya rynku zemel' sil's'kohospodars'koho pryznachennya: potribni vidpovidal'ni ta zvazheni rishennya. $\begin{array}{llll}\text { Visnyk ahrarnoyi nauky 9(97), 5-11. DOI: } & \text {. }\end{array}$ https://doi.org/10.31073/agrovisnyk201909-01

9. Novakovs'ka I.O. (2016) Upravlinnya mis'kym zemlekorystuvannyam [Management of urban land use]. Ahrar. nauka, 304.

10. Rynok zemli v Ukrayini: problemy ta perspektyvy. Chastyna 1. Pravove rehulyuvannya zemel'nykh vidnosyn $\mathrm{v}$ Ukrayini. Available at: http://bukvisnyk.cv.ua/misceve-samovryaduvannya/1781/

11. Vil'nyy rynok zemli - prodazh/kupivlya payu, tsina zemli, perevazhne pravo, bezoplatna pryvatyzatsiya ta pravky do zakonu pro zemlyu. Available at: https://agropolit.com/blog/481-vilniy-rinok-zemli--prodaj-kupivlya-payu-tsina-zemliperevajne-pravo-bezoplatna-privatizatsiya-ta-pravki-do-zakonu-pro-zemlyu

12. Tsiny na zemlyu, rynky zemli ta ekonomika [Land Prices, Land Markets, and the Broader Economy] Available at: https://www.linc

Новаковська И.О., Скрпнинк Л.Р., Ищенко Н.Ф.

ВВЕДЕНИЕ РЫНКА ЗЕМЛИ: АКТУАЛЬНЫЕ ВОПРОСЫ И ПЕРСПЕКТИВЫ РАЗВИТИЯ

Охарактеризовано особливості старту вільного ринку земель сільськогосподарського. Представлено наслідки відкриття ринку земель з точки зору економічної, земельної та юридичної складових у системі земельних відносин. Висвітлено перелік умов щฺодо купівлі-продажу земель сільськогосподарського призначення. Обтрунтовано специфіку функиіонування вільного ринку земель сільськогосподарського призначення. Надано характеристику основоположних нормативно-правових актів у сфері функціонування ринку земель. Здійснено порівняльний аналіз сучасного стану купівлі-продажу земельних ділянок фермерськими господарствами та 
агрохолдингами. Здійснено порівняння показників кількості укладених угод купівлі-продажу земельних ділянок сільськогосподарського призначення, середнє значення орендної плати за 1 га землі відповідно по областях та коливання цуін за 1 га землі при укладанні договорів купівлі-продажу. Проаналізовано зарубіжний досвід функиіонування ринку земель сільськогосподарського призначення з деталізацією факторів, які впливають на подальший розвиток. Зокрема розглянуто проблеми та потреби у функиіонуванні ринку земель Польщзі, Бразилії, США та Великій Британії. Запропоновано можсливість запровадження електронної систему по типу EMBRAESP, яка відстежує основні показники ефективності ринку міської нерухомості разом із міським законодавством, земельними нормами та великими проектами громадських робіт, які можуть вплинути на поведінку ринків нерухомості.

Ключовые слова: Земельные отночения, рынок земель, аренда земли, земельное законодательство.

Новаковська І.О., Скрипник Л.Р., Іщценко Н.Ф.

\section{ВПРОВАДЖЕННЯ РИНКУ ЗЕМЛІ: АКТУАЛЬНІ ПИТАННЯ ТА ПЕРСПЕКТИВИ РОЗВИТКУ}

Охарактеризовано особливості старту вільного ринку земель сільськогосподарського. Представлено наслідки відкриття ринку земель з точки зору економічної, земельної та юридичної складових у системі земельних відносин. Висвітлено перелік умов щзодо купівлі-продажу земель сільськогосподарського призначення. Обгрунтовано специфіку функціонування вільного ринку земель сільськогосподарського призначення. Надано характеристику основоположних нормативно-правових актів у сфері функціонування ринку земель. Здійснено порівняльний аналіз сучасного стану купівлі-продажу земельних ділянок фермерськими господарствами та агрохолдингами. Здійснено порівняння показників кількості укладених угод 
купівлі-продажу земельних ділянок сільськогосподарського призначення, середнє значення орендної плати за 1 га землі відповідно по областях та коливання ичін за 1 га землі при укладанні договорів купівлі-продажу. Проаналізовано зарубіжний досвід функціонування ринку земель сільськогосподарського призначення з деталізацією факторів, які впливають на подальший розвиток. Зокрема розглянуто проблеми та потреби у функціонуванні ринку земель Польщі, Бразилії, США та Великій Британії. Запропоновано можливість запровадження електронної систему по типу EMBRAESP, яка відстежує основні показники ефективності ринку міської нерухомості разом із міським законодавством, земельними нормами та великими проектами громадських робіт, які можуть вплинути на поведінку ринків нерухомості.

Ключові слова: земельні відносини, ринок земель, оренда землі, земельне законодавство. 